\title{
Macau Noir: Criminal Brotherhoods, Casino Capitalism, and the Case of the Post-Socialist Chinese Consumer
}

\author{
Tim Simpson
}

The Hong Kong film Casino is a gritty urban crime noir set in the Portuguese enclave of Macau in 1991, eight years before Portugal handed the territory back to the People's Republic of China. The Cantonese language film follows the rising fortunes of fictional Macau triad leader "Giant Wan" and his bitter conflict with rival gangster "Lo Ping." The film's opening scene depicts a lone, dark sedan slowly approaching the driveway of the Harbor Century Hotel and Casino. Three of Giant's henchman lean out of the car brandishing machine guns and collectively blast away the glass façade of the hotel entrance, showering security guards and unfortunate bystanders with bullets and shattered glass before squealing away.

The ostensible subject of the film is Giant, played by handsome Hong Kong leading man Simon Yam, but the film's motif is "representation." The film depicts Giant's rise in Macau's criminal underworld through the voice, eyes, and camera of a female television journalist who tells his story. We see Giant's face framed by the viewfinder of the journalist's video camera as he matter-of-factly relates the realities of survival on the streets and in the casinos of Macau. The journalist is both attracted to this tough, principled, "righteous and bold" gang leader who does not smoke or drink and cares for his mother, and repelled by his compulsive competitive instinct and his decision to resolve every dispute with brutal violence. But in her final news report at the film's conclusion she declares to the public that Giant must be understood as a type of "hero," a man for his difficult times.

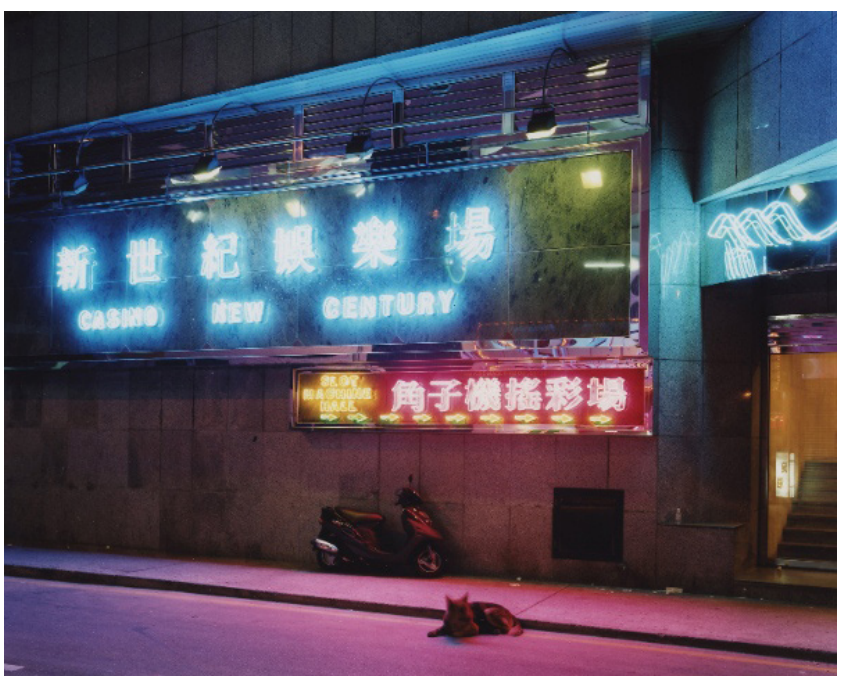

The film's sympathetic portrayal of Giant can be attributed to the fact that the film is actually an autobiographical story produced by Broken Tooth Koi, a prominent Macau gangster whose penchant for fame and notoriety led to 
features and interviews in Time and Newsweek and eventually to bankrolling the film based on his own life. The cinematic rivalry between Giant and Lo Ping presented in Casino mirrored the real-life conflict between Broken Tooth, leader of Macau's 14K triad, and his nemesis Market Wai of the Sun Yee On gang. Their public battles in Macau were brought to life again by the characters in the film, produced by Broken Tooth, and shot illegally in the streets, restaurants, apartments, and hotels of the city.

The film was released in 1999, the year of Portugal's handover of Macau to the PRC, at the height of a wave of violent crime that Macau experienced leading up to that event, much of it attributed to Broken Tooth and his gang.1 For 40 years Macau's local casino monopoly had been controlled by Hong Kong billionaire Stanley Ho who operated primarily out of his flagship Lisboa Casino. Ho's opportunistic business relationships with Chinese triads who controlled private gaming rooms in some Macau casinos, extending credit to high-stakes gamblers and collecting debts, had fostered increasing problems in the 1990s. As the date of Macau's return to the PRC crept closer, local gangsters perpetrated a series of increasingly violent acts in efforts to claim their shares of proceeds from lone sharking, extortion, smuggling, drugs, prostitution, and other vices in the colony before the Chinese authorities took over. Newspapers regularly reported lurid tales of arson, explosions, fire bombings of cars and motorcycles, shootouts between rival gang members (sometimes inside casinos), and targeted assassinations of government officials and gaming industry regulators. Yet no matter how brazen the actions of Broken Tooth and his criminal brotherhood, the Portuguese administration proved powerless to address the violence, punish the perpetrators, or maintain any semblance of law and order. The inability of the Portuguese state to properly administer even tiny Macau, the last remaining colony in its once substantial imperial archipelago, made many local Chinese anxious for the pending return of Macau to the authority and protection of the "motherland," and left Portuguese leaders scrambling to protect their nation's cultural and historical legacy in the territory as they prepared for decolonization.

Portugal controlled Macau for nearly 450 years, but the exact terms of the relationship were never clear. For several centuries Macau enjoyed an ambiguous status, never technically a European colony from the perspective of China, but at various times considered an "overseas territory" of Portugal and a "Chinese territory under Portuguese administration" (Goncalves, 2003). Cathryn Clayton (2010) refers to this liminal status as Macau's “sortof sovereignty." Due to its marginal position and distance from the metropole, Macau long managed to serve a number of pragmatic ends for both Portugal and China. Because of Portugal's neutrality in World War II, Macau was free from wartime Japanese occupation and a haven for spies, gamblers, and drifters from all over the world. Wartime smugglers took advantage of the city's location to move goods from Macau into China. Ho himself made his first fortune smuggling food and luxury goods across the border (Studwell, 2008). Even after the communist revolution in China, Macau maintained its status as an entrepot and a hub for business and trade carried out secretly by the PRC. Portugal's refusal to sign the Bretton Woods Agreement that controlled the sale of gold on the world market facilitated a thriving gold trade in Macau that was largely controlled by the Communist party. During the Korean War, the city allegedly served as a conduit for smuggling weapons into China in an effort to circumvent UN mandates (Dicks, 1984). However, by the 1990s this laissez-faire approach to governance that had served both countries well was tested by the waves of violent triad crime that rocked the city and that were depicted in the film Casino.

\section{The Benefits of Macanese Porosity}

Macau's "sort-of sovereignty" has been enhanced by the city-state's "porosity," a quality that affects its borders, cityscape and cultural life. In his meditation on the Italian city of Naples, Walter Benjamin (1978b) identified "porosity" as the quality that best characterized the Mediterranean Neapolitan urban environment. "Porosity refers to a lack of clear boundaries around phenomena, a permeation of one thing by another" (Gilloch, 1997, p. 25). Benjamin referred to the porous nature of Naples' architectural and social borders that might otherwise separate inside and outside, private and public, sacred and profane, past and present, work and leisure, day and night. We might say the same about Macau. Though geographically Iberian, Portugal nevertheless retains some Mediterranean characteristics, perhaps reflected in the notorious notion of "lusotropicalism" that Brazilian sociologist Gilberto Freyre (1946) identified as key to Portugal's maritime and colonial achievements. Freyre referred to a Portuguese quality that he thought emanated from a constellation of culture, geography, history, and climate and made the Portuguese more interculturally adaptable than other European colonial masters and therefore prone to produce cultural adulterations and ethnic hybrids in its colonies. The Portuguese brought a Mediterranean lifestyle to Macau 
four and a half centuries ago, fashioning an ambiguous and permeable territory, which was perhaps both the key to the country's success and ultimately the reason for its inability to control the violence at the close of the 20th century. The Mediterranean has played an important role in the world historical development of capitalism, first defined by the rising fortunes of Venice, Genoa, and Spain in the 16th century, and the opportunistic and symbiotic relationships among monarchies and state authorities on one hand, and pirates and privateers on the other (Braudel, 1992). The latter were often used as proxy navies to advance state maritime interests. Similar relations between state and non-state actors in Macau have served mutual benefits for centuries, and continue to do so today.

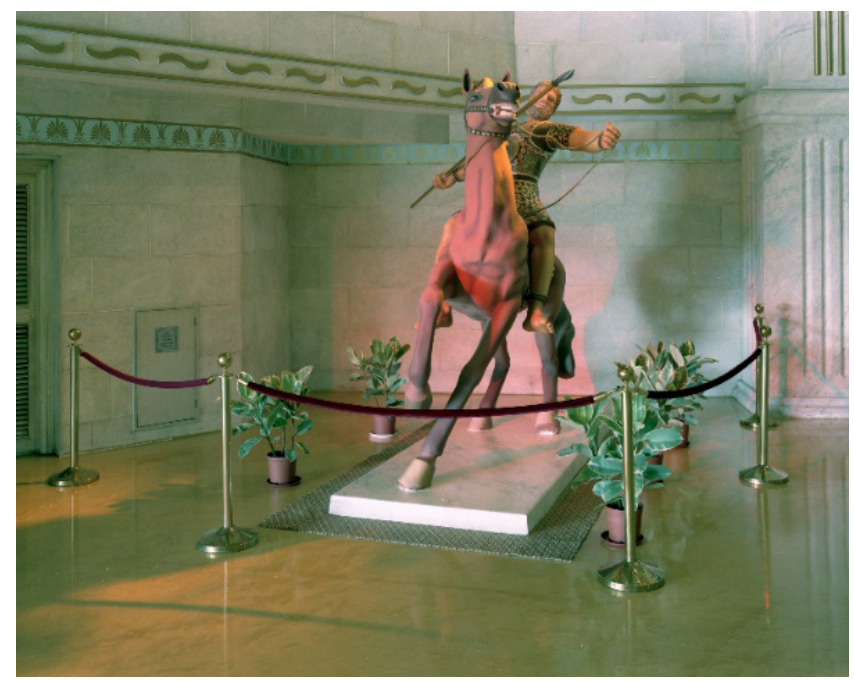

\section{Macau's Remarkable Recent Transformation}

Though Chinese triads still operate in the city and play an important role in the casino economy, today violent crime is virtually absent from the everyday life of Macau citizens. In an astounding reversal of fortunes, the tiny enclave is now the world's most lucrative site of casino gambling revenue. Following the handover, casino operators from North America and Australia entered the territory to compete with Stanley Ho for gambling revenues. The central government dismantled Ho's monopoly as part of a strategy to develop the industry and economy and to help establish law and order (Lo, 2005). Gritty and seedy locally-owned casino hotels now sit adjacent to opulent and phantasmagoric themed foreign structures like Sands, Venetian, MGM, Crown, Galaxy, and City of Dreams. North American gambling magnates Sheldon Adelson, Steve Wynn, and Kirk Kerkorian have raked in billions of dollars from Chinese gamblers in Macau's casinos over the past five years. When Adelson opened his Sands property in Macau - the first foreign casino in the territory after the handover - he recouped his initial $\$ 260$ million investment in ten months; Forbes estimated that from 2004-2006 Adelson earned \$1 million per hour from his investments (Forbes $400,2007)$. Wynn doubled his personal fortune in one year to $\$ 3.4$ billion from casino profits (Macau Daily Times, 2007, p. 3). In 2010, Macau's total casino revenues of $\$ 24$ billion tripled those of the Las Vegas strip (Master, 2011). The engine driving this seemingly "occult" (Comaroff and Comaroff, 2000) level of growth is the economy of the PRC: nearly half of the 26 million tourists who visited Macau in 2010 traveled from the mainland. Comprehending this remarkable transformation of the city and its economy in such a compressed time requires tracking the clue of "porosity" that disappears and reappears in Macau's cityscape and cultural life. By attention to the design of Macau's casinos and cityscape - and the motif of "representation" introduced in the film Casino - I hope to reveal the functional role the built environment of Macau plays in China's economic development via subjection of Chinese consumers. Fredric Jameson (1998) observes that the "emblematic significance" of contemporary architecture "lies in its immediacy to the social, in the "seam it shares with the economic," (p. 26) and it is within the immediacy of this seam or juncture that the post-socialist Chinese subject emerges. 


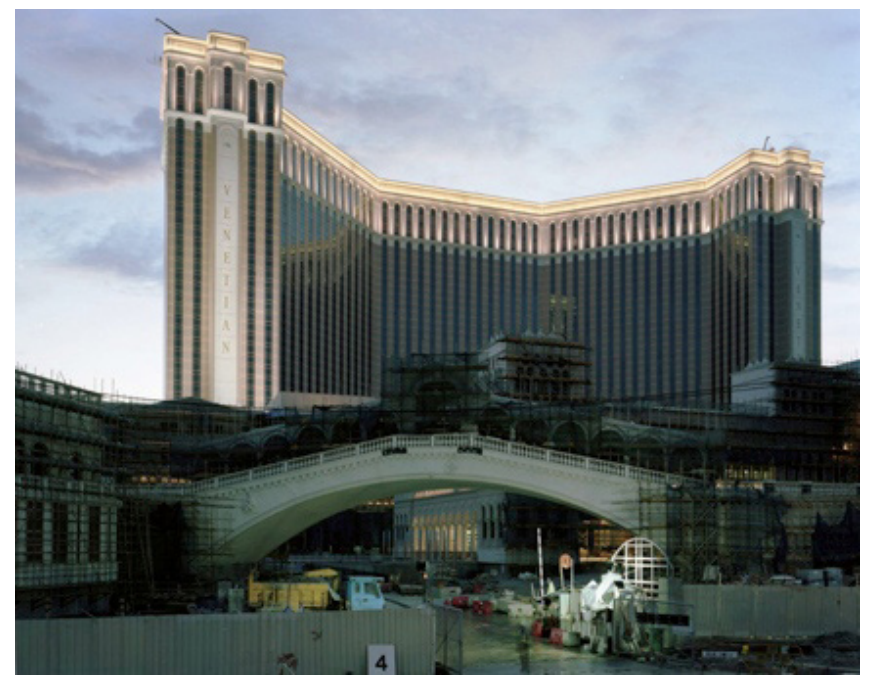

\section{Casino Architecture in Macau}

"This is how architecture, the most binding part of the communal rhythm, comes into being here: civilized, private, and ordered only in the great hotel and warehouse buildings on the quays; anarchical, embroiled, villagelike in the center, into which large networks of streets were hacked only forty years ago." - Walter Benjamin, "Naples"

To understand Macau a decade after Portugal's return of the colony to the PRC, it is tempting to search for clues in its newly-iconic casinos - Sands, Venetian, Wynn, MGM. If anything connotes the transformation of the Macau skyline it is the architectural styles of these new resorts; the glass curtain walls of Wynn and MGM that tower above the outer harbor, the exquisitely-stylized Italian theme of the Venetian. The Venetian is the largest casino - and one of the largest buildings - in the world. But Venetian, MGM and their ilk really say more about Las Vegas than Macau, more about the logic of North American financial speculation than a Portuguese city-state in China. Insight about Macau today is perhaps best sought in the local imitations of these foreign constructions. Many local casino owners who operated low-end joints under Ho's license for a percentage of the profits chose to renovate their properties to emulate the new players who entered the city. These indigenous responses to the Las Vegas aesthetic style represent the seemingly spontaneous discourse that emerges in, and from, the city itself. The most typical of Macau's domestic themed structures is arguably the otherwise overlooked Greek Mythology Casino on Taipa island.

As themed architecture, Venetian Macau and the Greek Mythology are polar opposites. The Venetian draws global attention and accolades for its mega size and superlative style. The Venetian "integrated resort" is a selfcontained world located far away from the daily life of Macau's residents near the airport on the reclaimed and otherwise inhospitable and uninhabited environment of Cotai. The Venetian anchors the so-called "Cotai Strip" that Adelson promised to construct if the local government granted him a casino license. The Venetian Macau, as Jean Baudrillard said of Venice itself, is the master of seduction. It captivates and distracts. Visitors disappear into this self-contained world, their movements captured by the cavernous interior, their gaze obstructed by window-less walls. The entire building executes a reversal as the outside environment of blue skies, promenades, city squares, and canals is mimicked under the roof. To paraphrase Benjamin, Macau's architecture is "Civilized, private, and ordered only in the great hotel and warehouse buildings on the quay." The pristine orderliness that draws international attention to the Venetian also identifies the structure as an interloper in the local scene.

On the other hand, the Greek Mythology Casino at the New Century Hotel attracts only derision. In concept, design, and execution it must be judged a failure. With a plaster statue of Poseidon surrounded by winged horses and a bevy of wide-eyed fish in the parking lot and Zeus guarding the casino entrance, the casino's aesthetic value is less the Venetian's middlebrow taste than accidental kitsch. However, tightly wedged between two bus stops, several apartment blocks, and the University of Macau, it is a quotidian feature for thousands of locals: students trudge past it on their way to the university; domestic workers steal free rides to the border gate on the casino's busses; and the large neon phoenix on the hotel's roof keeps watch over all. Indeed, although it borrows a theme from another 
time and place, the Greek Mythology Casino reflects the indigenous architecture of Macau: "Anarchical, embroiled, villagelike in the center," much like Benjamin observed of Naples.

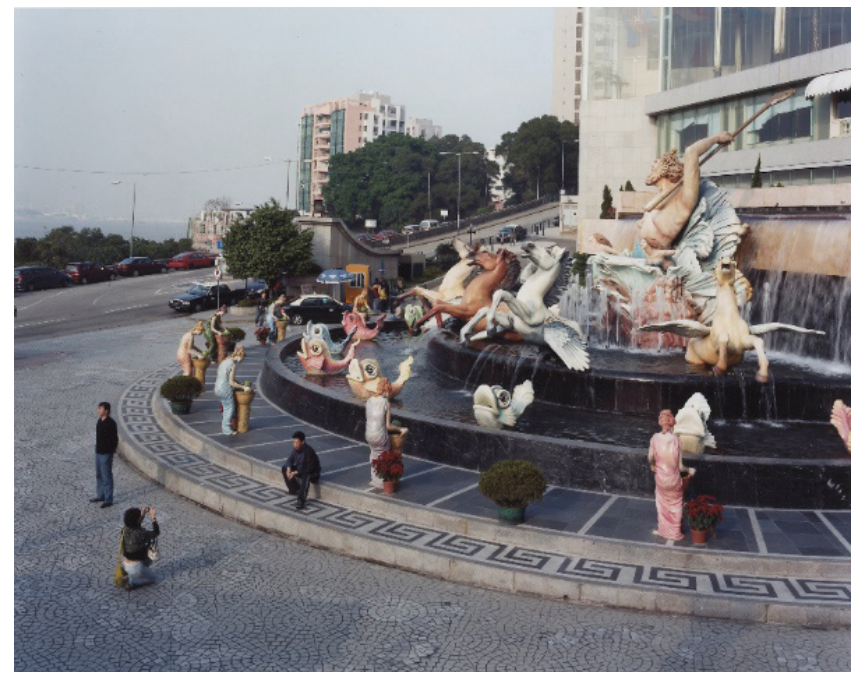

\section{The Permeability of Porosity and Governance of Macau}

The accessible Mediterranean porosity characteristic of Macau's indigenous architecture is repeated and writ large across the city's social and economic life. A certain susceptibility to loose boundaries is observable in the malleable status of Macau's gaming licenses that not only permitted Ho to lease out his license to cronies when he held the monopoly, but also allowed three post-handover concessions granted by the government to Ho, Wynn, and Lui Che Woo of Galaxy Entertainment Group to be transformed into six. A subsequent local government decision allowed each of the three original concessionaires to subdivide his license, thus doubling the total number of casino license holders. One new license went to MGM's Kerkorian in partnership with Ho's daughter Pansy Ho; another was awarded to Australian James Packer in the PBL/Melco partnership with Ho's son Lawrence Ho; and a third went to Adelson. Wynn profited $\$ 900$ million simply by selling his subconcession to PBL/Melco, revenue the government would have presumably collected had it merely awarded the subconcession directly.

Porosity creates diaphanous distinctions among local businessmen, government officials, and gangsters. This, in turn, contributes to Macau's ambiguous gaming regulations that permit independent, non-licensed operators to manage the city's lucrative VIP trade, which accounted for more than 70\% of casino revenue in 2010 (Master, 2011). Perhaps porosity contributes to the strange slippage in the uncertain Romanized spelling of Macau/o; the inconsistency of one country with two systems; and the gray areas that distinguish the nation, its Special Administrative Regions (SAR), and its Special Economic Zones (SEZ).2 Not least, the increasing porosity of the actual border between the Macau SAR and the Zhuhai SEZ is what helps generate such impressive tourist numbers. At the plebian level, the penetrable and paradoxical "international" border with the mainland feeds a daily business whereby Macau locals cross to the SEZ of Zhuhai to buy supplies of cigarettes, alcohol, meat, and canned goods in order to sell them to distributors in Macau for a small return (Brietung, 2007). In this way petty smuggling endures as a form of daily life. For those tourists from the PRC the border allows them to access a foreign territory with distinct economic and juridical regimes without actually leaving the nation. Such malleable membranes allow Macau to serve not only as a lucrative site of leisure for scores of tourists from the mainland but also to play a pedagogical role in transforming China's proletariat into capitalist speculators and consumers (Simpson 2008a, 2008b, 2009, 2010). "Tourism is an arena in which the production of cultural discourse penetrates everyday consumption, one in which Chinese subjects self-consciously consume complex representations of culture and respond to them in quotidian activities," contends Nyiri (2006). "As such, it is a key sphere in which the reinvention of the Chinese subject takes place" (p. 97). This is the city's significance ten years after the Handover. The Greek Mythology Casino is ground zero in this project. 


\section{The Mimetic Language of Themes}

In Travels in Hyperreality, perhaps the first serious meditation on themed attractions in the United States, Umberto Eco (1986) claimed that "the American imagination demands the real thing and to attain it, must fabricate the absolute fake." Nowhere is this peculiar American motivation better realized than in Las Vegas, with its resorts designed as three dimensional representations of New York and Paris, Egyptian pyramids and medieval castles. For Americans, according to Eco, "Knowledge can only be iconic, and iconism can only be absolute" (p. 53). When Las Vegas entrepreneurs like Adelson and Wynn entered Macau, they brought this iconic style to Macau - in fact, Venetian Macau and the Wynn Resort are each copies of their eponymous properties in Nevada. The American desire for the "absolute fake" is clearly evident in the Venetian Macau, with nearly life-size realizations of Piazza San Marco and the façade of Ducal Palace, statues of Adam and Eve and the winged lion of St. Marks, a digital reproduction of Veronesi's Venice Triumphant on the ceiling, and canals plied by Puccini-singing gondoliers.

The Venetian Macau is a marvel of what Benjamin (1978a) called our mimetic faculty, the innate human capacity to recognize and fashion resemblances among things: in this case, to recreate an entire city. More precisely, Venetian Macau is a copy of a copy of Venice; the "original" copy on which it is based is in Las Vegas. But in this case, the simulated Venetian has no relation to Macau. It is a relief map of some other place and time. It is impossible to even see Macau proper from the Venetian, and impossible to see outside at all from the casino, restaurants, or shopping mall. What appear to be windows on the façade of the building's base are revealed, at closer inspection, to be merely decorative fixtures through which no light may actually pass. The Venetian Macau has a Mediterranean motif but the design is not itself Mediterranean. That is, the structure is not porous or permeable like the indigenous architecture of Venice, Naples, or Macau. The Venetian has been designed for a global audience who will first glimpse the structure on a website or television program, and travel to its doors from the ferry terminal or airport by bus or taxi.

\section{The Creation of the Greek Mythology Theme, or Why is Poseidon in Macau?}

"Here, too, there is interpenetration of day and night, noise and peace, outer light and inner darkness, street and home." Walter Benjamin, "Naples"

As art or architecture, the Greek Mythology Casino fails to excite. Where the Venetian achieves a credible mimetic representation of Venice, the Greek Mythology appears more like a caricature. However, it is a mistake to judge the Greek Mythology on merely the veracity of the thematic elements or the execution of the theme. One should not view the Greek ideographs in the manner of Venetian, as attempts to faithfully recreate some alreadyexisting architectural form. Rather, the casino's centaurs, maidens, and horse-bound gods are better understood as enigmatic hieroglyphs, burghal dreams, Freudian slips from the tongue of the city itself (Simpson, 2008b). The porous character of Macau's urban spaces - and of the Greek Mythology Casino specifically - suggests the possibility of revelation, that something hidden just beneath a surface or behind a façade might suddenly reveal itself to the careful observer. Therefore, the hopeful adept must be prepared for the theme's significance to reveal itself.

Marx marveled at capitalism's ability to render the commodity as if by magic, divorced from the labor by which it was produced. At the Greek Mythology Casino, we must look beyond against such fetishism and ask instead, what series of events has brought Poseidon and Zeus to Macau? Reading backward from the Greek Mythology fountain we can find petrified in this palimpsest the story of the transformation of Macau over the past ten years. The trajectory of this tale moves from corrupt colonial casino capitalism to post-colonial, neoliberal global consumerism and it returns us to Casino's cinematic representation of the Macau nightlife.

In the pre-handover days of Macau the Greek Mythology property was called the New Century Hotel, and was the inspiration for the "Harbor Century Hotel," site of the shootout in the opening scene of Casino. The spectacular machine gun destruction of the hotel façade in the film mimicked an actual event, one violent episode in the long battle between Broken Tooth and Market Wai. Market Wai controlled the casino in the New Century Hotel using Stanley Ho's monopoly gaming license. Broken Tooth wanted people to believe that he controlled the city, and he made his point with both deadly violence and its gratuitous representation in his own autobiographical noir film.

By 1998 the actual violence in the city seemingly spun out of control. Residents and pundits alike could only shake their heads in disbelief when Macau's Undersecretary for Security remarked to the international press during 
the height of the tensions that tourists need not fear the local violence because, "our triad gunmen are excellent marksmen" who "would not miss their targets and hit innocent bystanders" (Lintner, 2007, p. 23). His personal driver was assassinated one year later (Lintner, 2007). Events culminated in spectacular fashion when the unoccupied car of Macau's chief of police exploded in the driveway of his home. Several hours later the chief, accompanied by his men, arrested Broken Tooth at a private dining room in Ho's Lisboa Hotel. Two days after the arrest, Casino opened in theatres in Hong Kong (though it was banned in Macau).

Two lengthy trials ensued to prosecute different sets of charges against Broken Tooth and his cronies, but the procedures faced many delays and postponements as one judge resigned and abruptly returned to Portugal, and witnesses failed to remember events or even to appear in court. There was no physical evidence to link Broken Tooth to the bombing of the chief's car and he was not prosecuted for that crime. The final trial revolved around his association with triad organizations. At the conclusion of the testimony in the second trial, a three-judge tribunal who had heard the case left the courtroom to privately view Casino. Following the screening, they declared that the depiction of Broken Tooth's life as a mafia leader in the film was indeed an accurate representation. Broken Tooth was ultimately found guilty of being a member of a triad organization and sentenced to 15 years in prison; the apparent veracity of the cinematic representation, in a city where things are not always what they appear, proved his downfall.

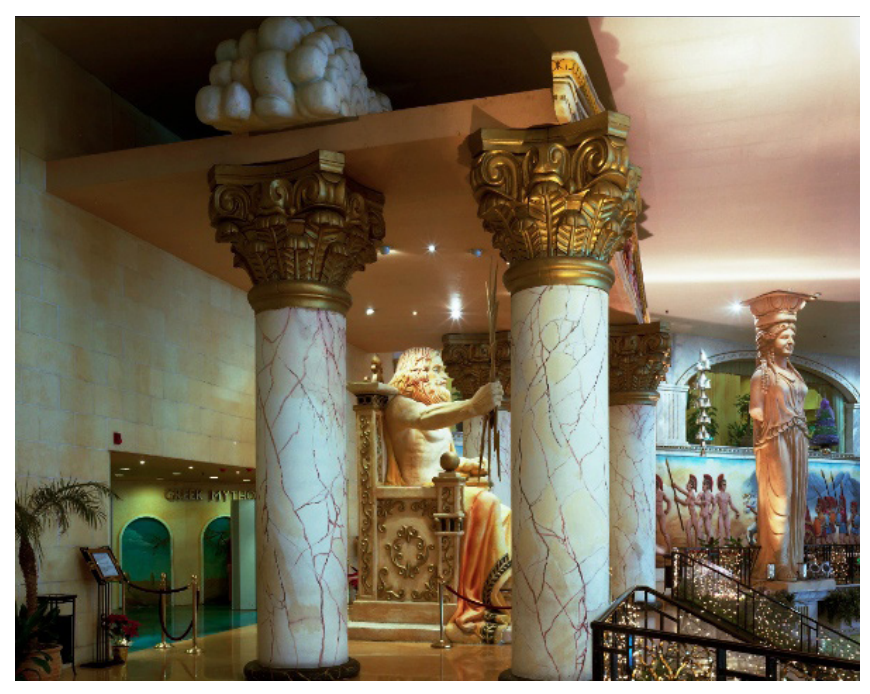

With Broken Tooth behind bars in a specially-built wing of the prison on Coloane island, the government prepared for the handover. The PRC hoped to restore order in the colony and the government made a strategic decision to liberalize the gaming industry and invite participation by foreign companies. The officials hoped that the presence of such companies would increase stability in the city and contribute to law and order. The development of the Greek Mythology themed façade of the former New Century Hotel emerged from this local set of concerns.

The original modernist concrete slab New Century Hotel had no particular pretense. As Jameson (1990) has remarked about modernist architecture more generally, the New Century Hotel name alluded to temporality. "In effect, it is through the experience of time that the modern is apprehended," says Jameson. "The temporality of high modernist architecture would be the way in which through an older city you arrive at something that stands for the future and that is radically disjointed from the older kind of city fabric" (p. 32). The "new century" that was approaching at the turn of the millennium would turn out to belong to China, and Macau would play an important role in China's rise.

In the wake of the new investment from foreign entrepreneurs a new luxurious and themed empire commenced construction in Macau appropriate for the new millennium. With an initial agreement to collectively spend US\$2 billion over ten years, the foreign gaming companies entered the city, subsequently exceeding their initial investment target ten fold. At the actual start of the 'new century,' the management of the New Century Hotel set about revitalizing the functionalist structure and designed the Greek Mythology theme, apparently determined that the structure would now represent something else than the famous gangland shootout. 
During the grand opening week of the newly-decorated Greek Mythology Casino, which happens to sit directly adjacent to the University of Macau where I work, the casino's boosters claimed daily crowds of up to 30,000 guests (Ho, 2005). While this number is likely exaggerated, there is no doubt that enormous throngs of tourists descended on the hotel. The adjacent street was lined day and night by dozens of busses that brought the tourists from the China border gate, and even from interior cities on the mainland, and deposited them at the hotel door. My Chinese colleagues at the university often commented on the obscure dialects spoken by many of the initial tourists, many of whom were taking advantage of the PRC's newly-introduced Individual Visitation Scheme (IVS) to make their first trip outside the mainland. The IVS provides travel VISAs for tourists from select provinces and cities to travel to Macau and Hong Kong without having to join a pre-sanctioned tour group. A German professor from Dresden remarked that she recognized the eager expressions on the tourists' faces, reminiscent of East Germans venturing into the West for the first time after the fall of the Berlin Wall. In both cases, the proletariat venture tentatively across a newly-porous border to glimpse a capitalist phantasmagoria on the other side. The first stop for many novice tourists in Macau is the Greek Mythology Casino.

\title{
| Gambling as Immaterial Labor
}

\author{
"With the pawnshop and lotto the state holds the proletariat in a vice: what it advances to them in one it takes back in the \\ other." - Walter Benjamin, "Naples"
}

The majority of Macau's casino revenues still derive from VIP gambling in private rooms. In the 1980s, Ho began sub-contracting such private gambling rooms in his casinos to agents who attract high-rollers from the region, bring them to Macau to gamble, and advance credit for gambling stakes (Siu, 2007). In Macau these agents are called "junket operators." Junket operators guarantee purchase of a certain quantity of chips from the casino each month, loan those chips as credit to gamblers, and later collect their earnings when the punters lose. The way this system operates in Macau is distinct from similar systems in other gaming jurisdictions like Nevada. Many of Macau's high rollers originate from China, and the PRC imposes complex restrictions on the amount of money travelers can move or carry out of the country. Therefore, high stakes play by gamblers from the mainland requires access to credit in Macau. Further, gambling debts are not legally enforceable under PRC law, so the creditor in Macau must be assured of his or her ability to entice losers to repay their debts after they have returned home. For this reason, junket operators need access not only to large amounts of cash, but to the ability to coerce extra-legal means of debt collection. The junket business is therefore synonymous with the triads and this is their foothold in Macau's gambling industry.

In its current incarnation, the Greek Mythology is the epitome of a grind casino, industry argot for a gaming facility aimed at the masses. The mass market is the opposite of the junket business. Grind casinos employ such strategies as low minimum bets on table games and ubiquitous low-priced slot machines to earn their daily "drop" off the spare change of construction workers, taxi drivers, and bored housewives. The Slot Director of Stanley Ho's gaming company notes that, where other Macau casinos only accept Hong Kong currency, "Our machines accept local coins."

We are the only company to do that in Macau, which has been a great benefit to our customers as they can walk in off the street and use their spare change. I would say the customer profile is 50-50 between grind and mid-market. We have construction workers, quite a lot of housewives and [casino] industry people - mostly middle class [customers]. ("One Country...”, p. 8)

While the majority of Macau's gaming revenue is derived from high-stakes VIP gambling, the Greek Mythology caters to a different type of punter. One Macau junket executive described the Greek Mythology Casino to me as "An insult to our industry," characterized by "low, low, low, low grind." The casino grind constitutes something akin to the "immaterial labor of gambling" (Lazzarato, 1996). Gambling, in turn, is a form of capitalist pedagogy (Simpson, 2011).

Overwhelmingly, tourists visit Macau to gamble. But gambling is not simply entertainment. Tourists from China visiting Macau's themed casino environments 'work' at being consumers. One characteristic that distinguishes Chinese gamblers from other groups of punters is the extent to which many of them approach gaming as a sort 
of intensive and serious labor, rather than leisure (see Lam, 2008). For example, such players eschew the free alcohol given away in Las Vegas casinos because intoxication interferes with their concentration. Instead, Macau casinos distribute free tea, orange juice, and milk. Chinese gamblers are noted for the intensity at which they play. In response, Macau's casinos are developing novel hybrid gaming systems that integrate electronic terminals and human dealers, allowing croupiers to serve more gamblers per shift and increasing the speed of each hand as well as the number of hands gamblers can play simultaneously. Such players intently study the outcomes of the games. Gamblers playing baccarat, the most popular game in Macau's casinos, keep detailed records of each card played from the shoe, employing their innate mimetic faculties in an effort to delineate patterns that break from random probabilities. Players 'squeeze' the cards, folding over card corners to peek at the face value, and the cards are destroyed like raw materials in a manufacturing process. In this way, the casino operates like a factory of productive gambling work at which the players dutifully labor. As a result of these efforts, the Greek Mythology Casino's interior fittings, carpets, and the felt surfaces of gaming tables are threadbare and worn, carrying fossilized traces of this intensive activity. Thus even the relatively new decorations look old. Much like Benjamin said of Naples, "One can scarcely discern where building is still in progress and where dilapidation has already set in."

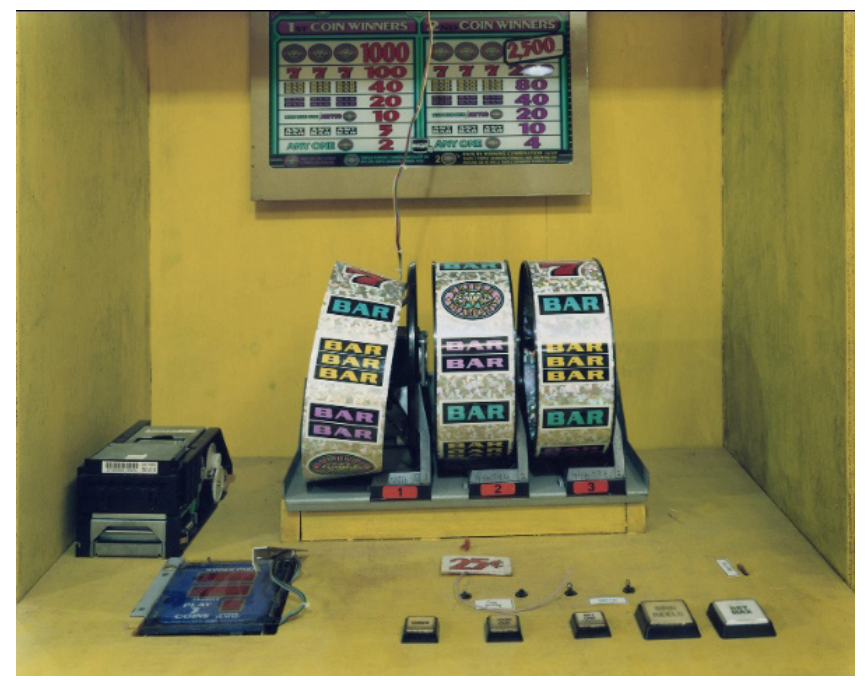

\section{Gambling as Capitalist Pedagogy}

"Lotto, alluring and consuming as nowhere else in Italy, remains the archetype of business life." - Walter Benjamin, "Naples"

As a form of capitalist pedagogy, casino gaming provides the most exaggerated model of speculative investment, an ersatz stock market without commodities or quarterly reports. In Macau gambling mimics the market. Gamblers from mainland China engage in a pedagogical activity that serves as a tutorial for capitalism. The stock market in China is sometimes referred to as the 'slot machine' (dubo ji) (Barboza, 2007). If many Chinese labor at gambling, they (like their western counterparts) 'play' the market. 'Investing in the stock market [in Shanghai] is frequently referred to, as in English, by the verb "play," in contrast with "work" (Hertz, 1998: 135). One journalist notes that Chinese "Brokerage firms are set up like casinos. Investors drink tea, smoke and chat as they input trades on computers lined up like slot machines. Instead of dropping in coins, they swipe bank cards to pay for shares' (Areddy, 2007: 32). Commentators often remark on the lack of reliable information about corporate performance and governance in China's stock market, which leads market players to make investment decisions much like they might bet on baccarat.

'I don't know how to choose a stock,' says a 61-year-old retiree who gave her name as Miss Hou at a local brokerage house a few weeks ago. 'But I trust those technology companies. Maybe the names of some companies sound lucky to me, so I 
choose to buy these stocks' (Barboza, 2007).

Like the stock market, gambling allows for economic return to be divorced from individual labor. 'The gambler as financial speculator does not resist capitalist prescriptions, but rather fundamentally embodies them,' writes Gilloch (1997). 'Capitalism formalizes the activity of the gambler and his desire to make money through the institution of the stock market' (p. 158). We might understand such casino gambling as a form of labor that mimics capitalist speculation and consumption, and the themed casino plays a productive role in this process. When Chinese tourists visit those casinos, their activities contribute to the development of the socialist-market economy on the mainland.

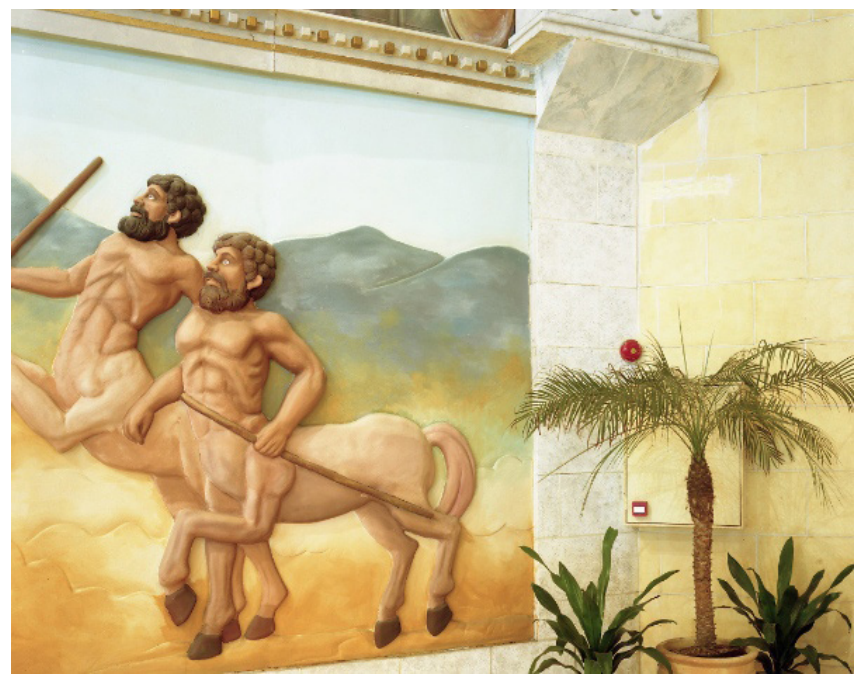

\section{Themes, Athenaeums, and The Meaning of Macau's Mediterranean Motifs}

Market Wai and the Greek Mythology Casino aside, the themed environments that proliferate throughout Macau today are consistent with similar themed structures in cities around the world. Van Melik, et. al. (2007) identify two tendencies characteristic of twentieth century urban design that are reflected in Macau's contemporary urban spaces: creating secured space in an effort to reduce urban fear, and creating themed space in an effort to induce fantasy. They argue, however, that these are not contradictory impulses but are rather "two aspects of the same tendency towards greater control over public space" (p. 25-26).

Macau's themed spaces are also part of the dialectic of fear and fantasy. It was in part the public perception of Macau as a dangerous haven of violent triads at war in the streets and casinos that motivated the city administration to end the gaming monopoly and invite investment from foreign companies. It was the representation of that violence in the media that scared tourists and frustrated residents. It was Broken Tooth's cinematic representation of this own life in Casino that proved his downfall by appearing too close to reality, by exposing the mimetic slippage between the original and the copy. Perhaps following Churchill's dictum that "we make our buildings, and then our buildings make us," the government's implicit strategy was to supplant Macau's porous and chaotic Mediterranean urban space and all that it represented with impermeable and comforting themed structures. The Sands Casino was the first such project. The largest casino in the world at the time it was built, the Sands' enormous, brightlyilluminated gaming floor was designed for maximum visibility. The stadium-style design allows the entire main floor to be observed by people standing on the open floors that circle above it, contrasting dramatically with the tiny, dark, and cramped basement areas and private rooms of what was then Ho's flagship Lisboa Casino. The Sands signaled a new era in Macau - not "gambling" but "gaming," a pure, wholesome, and safe form of play overseen by benevolent corporate stakeholders and financiers of the transnational capitalist class rather than by Broken Tooth and his gang. Even the perfumed air of the Sands provides an olfactory indication of an innocuous and controlled environment. The Venetian Macau, Adelson's encore to his Sand's debut, perfected this trend. It offers an entirely cloistered 
“integrated" gaming and leisure environment, set apart from the city on Adelson's trademarked Cotai replication of the Las Vegas strip. The ultimate goal of all these efforts is impermeability - panopticism, transparency, contractual obligations, enforced regulations, controlled access, and privatized, pseudo-public space.

But there is another mimetic Macau beneath such pristine and perfected themed surfaces. Macau's significance is not measured merely in the veracity of its imitations. The cognoscente must approach themed reliefs like those of the Greek Mythology as portent runes and ciphers. To properly understand themed mimesis, a "mimetic" reading is necessary, "the divination of the secret from the surface" (Gilloch, 2002, p. 44). And what recondite secrets lurk among the Greek ideographs in the hotel? What disquieting events are witnessed by the centaur's wide-eyed stare?

The "motherland" is a vast exchequer of socialist workers each eager to glimpse fantastic, phantasmagoric alien worlds. The technocrats in the PRC devise realms those workers may visit - the SARs and SEZs - engineering exit VISA regulations, individual travel schemes, and Golden Week holidays to ensure a steady flow of tourists into Macau. The Greek Mythology Casino dutifully collects the tourists at the border by the busload, delivering them daily to labor on the well-worn gaming floor. But it could be said that the casino, as Benjamin said of the Neapolitan house, "is far less the refuge into which people retreat than the inexhaustible reservoir from which they flood out." It is here at the Greek Mythology Casino, in a ruinous and labyrinthine Portuguese city on the edge of the "middle kingdom," that those erstwhile Mediterranean gods grind China's socialist comrades, as if by alchemy, into post-socialist consumers. Macau's casinos earned $\$ 24$ billion in revenues in 2010, and that number is projected to double by 2015 (Master, 2011). The profits derive from Chinese tourists who regularly retreat from socialism on the mainland to gamble in themed casinos across the border. The Greek Mythology casino does not aspire to be a seductive "absolute fake" like the Venetian. On the contrary, the seemingly idiosyncratic and incongruous Greek hieroglyphs in the casino are an unerring allegory of an irrational and mythic capitalism.

\section{Acknowledgments}

This is a substantially revised and expanded version of the article, "Macau's Mediterranean motifs" that was originally published in the magazine World Architecture, 12: 104-11. The author would like to thank Tsinghua University for granting permission to use portions of the original article here.

\section{Endnotes}

1. For detailed accounts of this period of violent crime in Macau see Clayton (2011), Pina-Cabral (2002, 2005) and Regan (2011). My account of the period is derived from these sources.

2. Local government directives indicate that in official documents the city's name should be spelled "Macau" in Portuguese, and "Macao" in English, except in the name University of Macau/ Universidade de Macau" which retains the "u" regardless of the language. However, the spelling of the city name in everyday use seemingly follows no particular logic. 


\section{References}

Areddy, J.T. (2007) 'To Chinese investors, ' 8 ' is great', Wall street journal, 24 May: 1, 32 .

Barboza, D. (2007) 'From Shanghai, tremors heard around the world,' New York times, 28 February: 1.

Benjamin, W. (2008a) “On the mimetic faculty," in P. Demetz (Ed. and Trans.) Reflections. New York: Schocken.

Benjamin, W. (2008b) "Naples," in P. Demetz (Ed. and Trans.) Reflections. New York: Schocken.

Braudel, F. (1992) The Mediterranean and the Mediterranean world in the age of Philip II. London: HarperCollins.

Breitung, W. (2007) Overcoming borders living with borders: Macao and the integration with China. (Macau: Instituto Cultural do Governo da R.A.E. de Macau.

Clayton, C (2010) Sovereignty at the edge: Macau and the question of Chineseness. Cambridge: Harvard University Press.

Comaroff, J. and Comaroff, J. (2000) "Millennial capitalism: First thoughts on a second coming," Public culture 12:291-343

Dicks, A.R. (1984) "Macao: legal fiction and gunboat diplomacy," Leadership on the China coast, Ed. G. Aijmer. Richmond, Surrey: Curzon: 90-127

Eco, U. (1986) Travels in hyperreality. Orlando: Harcourt Brace \& Co.

Forbes 400 (2007) http://www.forbes.com/lists/2007/SA/rich list07 Sheldon-Adelson-ER90.html

Freyre, G. (1946) The masters and the slaves: A study in the development of Brazilian civilization, S. Putnam (trans). New York: Alfred A Knopf.

Gilloch, G. (2002) “Benjamin's London, Baudrillard's Venice,” in N. Leach (ed) The hieroglyphics of space: Reading and experiencing the modern metropolis. London: Routledge.

Gilloch, G. (1997) Myth and metropolis: Walter Benjamin and the city. London: Polity Press.

Hertz, E. (1998) The trading crowd: An ethnography of the Shanghai stock market. Cambridge: Cambridge University Press.

Regan, J (2011) “Into the Glare," Inside Asian gaming, May: 8-12.

Jameson, F. (1990) "Envelopes and enclaves: The space of post-civil society - an architectural conversation," Assemblage, 17: 32-37.

Jameson, F. (1998) "The brick and the balloon: Architecture, idealism, and land speculation. New left review, 228, MarchApril: 25-46.
Ho, A. (2005) “Macau's Greek Mythology Casino reveals its expansion plan," www.globalgamingnews.com/new_asia/ macau-greek-mythology-casino.html, retrieved 5/13/2005.

Lam, D. (2008) "An observation study of Chinese baccarat players." UNLV gaming research and review journal, 11(2): 63-73.

Lazzarato, M. (1996) “Immaterial labor." In P. Virno and M. Hardt (eds) Radical

thought in Italy: A potential politics, p. 132-146. Minneapolis: University of Minnesota Press.

Lintner, B. (2007) Stanley Ho’s luck turns sour," Far eastern economic review, May: 20-23.

Lo S. H. (2005) "Casino politics, organized crime and the postcolonial state in Macau', Journal of contemporary China 14: 207-24.

Macau Daily Times (2007) “US \$3.4 billion windfall a Wynn win," 17 Sept: 3

Master, F. (2011) "Macao sets its sights on the mass market," International herald tribune, May 17: 17.

Nyiri, P. (2006) Scenic spots: Chinese tourism, the state, and cultural authority. Seattle: University of Washington Press.

"One country, many marketing systems" (2009) Inside Asian gaming, July: p. 7-14.

Pina-Cabral, J. (2002) Between China and Europe: Person, culture and emotion in Macao. London: Continuum.

Pina-Cabral, J. (2005) "New-age warriors: Negotiating the handover on the streets of Macao." Journal of romance studies, 5(1): 9-22.

Simpson, T. (2008a), "The commercialization of Macau's cafes." Ethnography 9(2): $225-262$.

Simpson, T. (2008b) "Macao, capital of the twenty-first century?" Environment and planning d: Society and space, 26: $1053-1079$.

Simpson, T. (2009) "Materialist pedagogy: The function of themed environments in post-socialist consumption in Macao," Tourist studies, 9(1): 60-80.

Simpson, T. (2011) “'Neoliberalism with Chinese characteristics': Consumer pedagogy in Macao," Cities and fascination: Beyond the surplus of meaning, Ed. H. Schmid, W. Sahr, J. Urry, Ashgate. 
Siu, R.C.S. (2007) "Formal rules, informal constraints, and industrial evolution - the case of the junket operator regulation and the transition of Macao's casino business." UNLV gaming research and review journal, 11(2): 49-62.

Studwell, J. (2008) Asian godfathers: Money and power in Hong Kong and Southeast Asia. Grove Press.

Van Melik, R., Van Aalst, I., Van Weesep, J. (2007) "Fear and fantasy: The development of secured and themed urban space," Journal of urban design 12(1): 25-42. 